\title{
Cinema Therapy to Improve The Counselor's Understanding about Dealing with Feeling Skills for Students
}

\author{
D. Setiawati \\ Universitas Negeri Surabaya \\ Surabaya, Indonesia
}

\author{
E. Winingsih \\ Universitas Negeri Surabaya \\ Surabaya, Indonesia
}

\begin{abstract}
The research has the purpose to know the utilization of cinema therapy to improve the counselor's understanding about dealing with feeling skills for students. The skills consist of how to know, understand and express the feeling in the right situation. The kind of this research is qualitative research. The instrument of collecting data is interview and questionnaire. Subjects of this research are counselors in junior high school. Intervention strategies used for the experimental group is experience-based learning. This intervention strategy consists of four stages, namely: a real experience, reflection, conceptualization/abstract thinking and application. The result of research is cinema therapy can improve the counselor's understanding dealing with the feeling skills for the students.
\end{abstract}

Keywords - Cinema therapy, dealing with feeling skills for students

\section{INTRODUCTION}

The whole figure of the competence of counselor consists of 2 different components but integrated in praxis so that can't be separated, that is academic competence and professional competence $[2,12,13]$. The academic competence of a Professional Counselor consists of the ability to: 1) Know deeply the counselee to be served; 2) Master the theoretical and procedural repertoire and technology in guidance and counseling. Professional counselor competence is formed through training in applying academic competence in guidance and counseling [14]. It's just not that all competencies can be owned by the counselor. One of them is the professional competence in training the students to deal with the feeling skills [15]. Though many problems faced by junior high school children who allegedly because they can't deal with their feelings. While the teachers do not have enough opportunities to get training to improve their competence for various reasons.

Messina (2009), differentiate the feelings into two groups: the negative feelings and positive feelings [5]. Humans have a tendency to enjoy the positive feelings and feel uncomfortable with the negative feelings. But when both positive and negative feelings appear excessive and could not be controlled, it will cause new problems, it could even cause a person does not know what to do (Dlugokinski 2010). Some studies have shown that feelings can be dealt by some strategies $[5,9,1,4,8]$.

To improve the understanding of the skills to deal with the feelings can be done by using cinema therapy. It designed in a training using experiential learning with four stages: real experience stage, reflection stage, conceptualization stage, and application resistance. Cinema therapy has emerged as a useful intervention for adults, teenagers, and children. This strategy is presented through written materials, audio, video, movies or slides. According to Michael (In Sapiana, 2014) "cinema therapy is the process of using film in therapy as a metaphor to enhance client's growth and insight." [6].

Byrd [6] identifies "the goal of cinema therapy or video work as the potential means to open discussions in therapy". Movies can show ordinary life and let counselees find guidance in work. In addition, cinema therapy is a creative therapeutic technique in which a trained psychotherapist uses film as a therapeutic tool to assist clients. In other words, through cinema therapy the insights and understanding of counselors about the importance of the skills to deal with the students' feelings will increase.

\section{METHOD}

This study uses a qualitative approach. To see a change in the counselor's understanding in dealing with the students' feeling skills and the extent to which the influence of the use of cinema therapy enhance the counselor's understanding before and after treatment is used interview techniques and open questionnaire. The interview technique is a direct interview $[10,11]$.

Intervention strategies used for the experimental group is experience-based learning (EL) by Kolb (1984) [3]. This intervention strategy consists of four stages, namely: a real experience, reflection, conceptualization/abstract thinking and application. The short explanation is as follows: 
(a) Real Experiences Stage

Stage real experience carried out by taking the counselors experienced a sense of many kinds of feeling by watching the cinema. Then, counselor explains what the kind of feeling they feel. After that the counselor in the stage of reflective observation.

(b) Reflective Observation Stage/ Reflections

The reflection stage obtained through the observation conducted by the counselors to observe the feelings they experienced in the cinema and then compare it with the real life, and it resulted the conclusion of the feelings they experienced, whether it is kind of negative feelings and uncomfortable for them or etc.

(c) Conceptualization Stage

Conceptualization stage is a stage for understanding the principles of the feelings that have been reflected. Through the participant's understanding, they are expected to have a new concept in dealing with new embarrassment which consisted of relaxation, positive self-talk and change the negative thoughts into positive thoughts.

(d) Active experimentation stage/ application

Active experimentation stage is the stage of an opportunity to study subjects to apply the material obtained in training to deal with feelings in the real situations. The research subjects were given the task of noting his situation earlier with the formats that will be provided

\section{RESULTS AND DISCUSSION}

The results obtained during the training are many teachers who feel helped by the ability to deal with the feelings. The implementation of scenario training is divided into four stages. The first stage is the stage of real experience. At this stage some video shows to see how far the ability of the counselor to know the feelings that arise in the cinema. The first video is a short 'silence love' movie that tells about the struggle of a dumb father who loves his son, but the child is ashamed to have a dumb father. Until finally he was faced with the conditions between life and death due to suicide but the sacrifice of his father who taught him the true meaning of love.

The second video tells the story of the accident of a woman by a train but still alive. The third video is about a baby jig.

In this stage, the counselors tell many kinds of the feeling that arises like sad, love, angry, afraid, shy, etc.

After that, the counselor learns how to understand the feelings by identifying the thoughts, feelings, and reactions of the accompanying body when the feelings arise as a form that the counselor understands the feelings that exist. This happened in the Reflective Observation Stage / Reflections.

After that the counselors are trained for a simple relaxation, then turn negative thoughts into positive and the final thoughts are positive self-talk in the conceptualization

stage. At the conceptualization stage, students are conditioned to be able to conceptualize new ways of managing negative feelings. The way it is done is relaxation, talking positively to yourself and turning negative thoughts into positive thoughts (restructuring cognitive). Research conducted Smeltzer \& Bare (2002), found that relaxation can reduce the stress, both physical and emotional stress, and the intensity of pain and anxiety.

After the training the counselors were asked to write an evaluation sheet and were given the task of training students with the skills to deal with feelings and asked to report the results of the training. The counselor training results are written in the format provided. The results show that the counselor has understood the nature of the skill in dealing with the student's feelings and able to train the students' dealingsense skills. Just to raise the feeling of using tailored to the condition of the school. For schools that allow to show new videos have used new videos but some are using video, music or real-life experiences.

The results of changes in understanding between the counselor before and after applied cinema therapy are as follows:

TABLE I. The COUNSELOR'S UndERSTANDING OF DEALING WITH FEELING SKILL STUDENTS

\begin{tabular}{ccc}
\hline Subject & Pretest & Posttest \\
\hline A & Being able to recognize & Being able to recognize \\
& feelings, have not been & feelings that arise well, bias \\
able to discern the & distinguishes the \\
accompanying body & accompanying body \\
reactions when negative & reactions when negative \\
feelings arise, choosing & feelings arise and can \\
how to express old & choose how to express the \\
& feelings & feeling in the right situation
\end{tabular}

B Can recognize feelings, able to distinguish the body's accompanying reaction when negative feelings arise, choose how to express old feelings

Being able to recognize feelings that arise well, bias distinguishes the accompanying body reactions when negative feelings arise and can choose how to express the feeling in the right situation

$\mathrm{C}$ feelings, have not been
able to distinguish the
body's accompanying
reactions when negative
feelings arise, choosing
how to express old
feelings

D Being able to recognize feelings, have not been able to discern the accompanying body reactions when negative feelings arise, choosing how to express old feelings
Being able to recognize feelings that arise well, bias distinguishes the accompanying body reactions when negative feelings arise and can choose how to express the feeling in the right situation

Being able to recognize feelings that arise well, bias distinguishes the accompanying body reactions when negative feelings arise and can choose how to express the feeling in the right situation 


\begin{tabular}{|c|c|c|}
\hline Subject & Pretest & Posttest \\
\hline$E$ & $\begin{array}{l}\text { Unable to recognize } \\
\text { feelings, have not been } \\
\text { able to distinguish the } \\
\text { body's accompanying } \\
\text { reactions when negative } \\
\text { feelings arise, choosing } \\
\text { how to express old } \\
\text { feelings }\end{array}$ & $\begin{array}{l}\text { Being able to recognize } \\
\text { feelings that arise well, bias } \\
\text { distinguishes the } \\
\text { accompanying body } \\
\text { reactions when negative } \\
\text { feelings arise and can } \\
\text { choose how to express the } \\
\text { feeling in the right situation }\end{array}$ \\
\hline $\mathrm{F}$ & $\begin{array}{l}\text { Unable to recognize } \\
\text { feelings, have not been } \\
\text { able to distinguish the } \\
\text { body's accompanying } \\
\text { reactions when negative } \\
\text { feelings arise, choosing } \\
\text { how to express old } \\
\text { feelings }\end{array}$ & $\begin{array}{l}\text { Being able to recognize } \\
\text { feelings that arise well, bias } \\
\text { distinguishes the } \\
\text { accompanying body } \\
\text { reactions when negative } \\
\text { feelings arise and can } \\
\text { choose how to express the } \\
\text { feeling in the right situation }\end{array}$ \\
\hline Subject & Pretest & Posttest \\
\hline $\mathrm{G}$ & $\begin{array}{l}\text { Can recognize feelings, } \\
\text { able to distinguish the } \\
\text { body's accompanying } \\
\text { reaction when negative } \\
\text { feelings arise, choose } \\
\text { how to express old } \\
\text { feelings }\end{array}$ & $\begin{array}{l}\text { Being able to recognize } \\
\text { feelings that arise well, bias } \\
\text { distinguishes the } \\
\text { accompanying body } \\
\text { reactions when negative } \\
\text { feelings arise and can } \\
\text { choose how to express the } \\
\text { feeling in the right situation }\end{array}$ \\
\hline $\mathrm{H}$ & $\begin{array}{l}\text { Unable to recognize } \\
\text { feelings, have not been } \\
\text { able to distinguish the } \\
\text { body's accompanying } \\
\text { reactions when negative } \\
\text { feelings arise, choosing } \\
\text { how to express old } \\
\text { feelings }\end{array}$ & $\begin{array}{l}\text { Being able to recognize } \\
\text { feelings that arise well, bias } \\
\text { distinguishes the } \\
\text { accompanying body } \\
\text { reactions when negative } \\
\text { feelings arise and can } \\
\text { choose how to express the } \\
\text { feeling in the right situation }\end{array}$ \\
\hline I & $\begin{array}{l}\text { Can recognize feelings, } \\
\text { able to distinguish the } \\
\text { body's accompanying } \\
\text { reaction when negative } \\
\text { feelings arise, choose } \\
\text { how to express old } \\
\text { feelings }\end{array}$ & $\begin{array}{l}\text { Being able to recognize } \\
\text { feelings that arise well, bias } \\
\text { distinguishes the } \\
\text { accompanying body } \\
\text { reactions when negative } \\
\text { feelings arise and can } \\
\text { choose how to express the } \\
\text { feeling in the right situation }\end{array}$ \\
\hline $\mathrm{J}$ & $\begin{array}{l}\text { Unable to recognize } \\
\text { feelings, have not been } \\
\text { able to distinguish the } \\
\text { body's accompanying } \\
\text { reactions when negative } \\
\text { feelings arise, choosing } \\
\text { how to express old } \\
\text { feelings }\end{array}$ & $\begin{array}{l}\text { Being able to recognize } \\
\text { feelings that arise well, bias } \\
\text { distinguishes the } \\
\text { accompanying body } \\
\text { reactions when negative } \\
\text { feelings arise and can } \\
\text { choose how to express the } \\
\text { feeling in the right situation }\end{array}$ \\
\hline K & $\begin{array}{l}\text { Being able to recognize } \\
\text { feelings, have not been } \\
\text { able to discern the } \\
\text { accompanying body } \\
\text { reactions when negative } \\
\text { feelings arise, choosing } \\
\text { how to express old } \\
\text { feelings }\end{array}$ & $\begin{array}{l}\text { Being able to recognize } \\
\text { feelings that arise well, bias } \\
\text { distinguishes the } \\
\text { accompanying body } \\
\text { reactions when negative } \\
\text { feelings arise and can } \\
\text { choose how to express the } \\
\text { feeling in the right situation }\end{array}$ \\
\hline
\end{tabular}

IV

\section{CONCLUSION}

This study was conducted to test the utilization of cinema therapy to improve the counselor's understanding of the importance of students' dealing-sense skills. The results show that the counselor has understood the nature of the skill in dealing with the student's feelings and able to train the students' dealing-sense skills. Just to raise the feeling of using tailored to the condition of the school. For schools that are able to show new videos have been able to recognize feelings, have not been able to distinguish the accompanying body reactions when negative feelings arise, choose how to express old feelings using new videos but some are using video, music or real experiences. Based on the measurements of conditions between before and after training are: Before treating the counselor is able to recognize the feelings that emerge well, but unable to distinguish the body's reaction that accompanies when negative feelings arise and can choose how to express old feelings. Meanwhile, after the treatment, the counselors are able to recognize the emerging feelings, the bias distinguishes by the accompanying body reactions when negative feelings arise and able to choose how to express a better feeling in the right situation.

Basically, dealing with feelings can be learned and trained to everyone through intensive training, especially through school training programs (Hallahan \& Kauffman, 1991). The results showed that the skills training to deal with the feelings with experiential learning-based training methods proved a success of the treatment.

\section{REFERENCES}

[1] R. Bolton, People Skills, Sydney: Prentice Hall of Australia, 1986

[2] Depdiknas, Penataan Pendidikan Profesional Konselor dan Layanan Bimbingan dan Konseling dalam Jalur Pendidikan Formal. Jakarta: Depdiknas, 2007

[3] D. A. Kolb, Experiential Learning, Englewood Cliffs, NJ: Prentice Hall, 1984

[4] Knowles, D. Ruth, Worry Journal and Guilty Time “American Journal of Nursing", 1981, 2035

[5] Messina and J. James, Getting in Touch With Feelings. American Psychological Association, 2009

[6] Sapiana, Sapiana, Pengaruh Bimbingan Kelompok Teknik Cinema therapy Terhadap Motivasi Belajar Siswa Kelas X Multimedia Di Smk Negeri 1 Limboto Kabupaten Gorontalo. Other Thesis, Universitas Negri Gorontalo, 2014. (online). (http://eprints.ung.ac.id/2358/2/2013 1-86201-111409055-bab1-25072013074842.pdf). Diakses tanggal 21 Mei 2015.

[7] Smeltzer \& Bare, Keperawatan medikal bedah. Transl. Agung Waluyo Edisi 8 Vol.1. Jakarta: EGC, 2002

[8] Sprafkin, P. Robert, Social Skills for Mental Health A Structure Learning Approach. USA: Allyn and Bacon, 1993

[9] M. Swart, R. Kortekaas, and A. Aleman, Dealing with Feelings: Characterization of Trait Alexithymia on Emotion Regulation Strategies and Cognitive-Emotional Processing, in PLoS ONE 4(6): e5751. doi:10.1371. Journal, 2009

[10] B Louise and W Alison, "Collecting data using a semi-structured interview: a discussion paper", in Journal of Advanced Nursing, Vol 19, pp 328-335, 1994

[11] O Raymond, "Advantages and Disadvantages of Four Interview Techniques in Qualitatives Research", in Qualitative Social Research Sozialforschung, Vol. 7 No. 4, 2006 
[12] M Eraut, Developing Profesional Knowledge and Competence. New Fetter Lane, London: RoutledgeFalmer, 2003

[13] Gall'alba Gloria and S Jörgen, "Educationg for competence in profesional practice" in Instructional Science, Vol. 24 Issue 6, pp 411437, 1996

[14] W D Linda, B A Greg, and C Chari, "Linking school counselors and student success: a replication of student success skills aproach targeting academic and social competence of students" in Professional School Counseling, Vol. 8 No. 5, June, 2005

[15] Marc A Brackett and Nicole A Katulak, Applying Emotinal Intellegence a Practitioner's Guide. C Joseph and D M John. New York: Psychology Press, 2007 